\title{
A user-friendly guide on how to obtain and accurately interpret information from metabolic databases
}

\author{
C. Cadenas $\cdot$ R. Marchan
}

Published online: 18 August 2011

(C) Springer-Verlag 2011

In the past years, the use of bioinformatical and modelling techniques in research has dramatically increased. Examples of applications include the identification of overrepresented transcription factors and biological functions of differentially expressed genes (Glahn et al. 2008; Godoy et al. 2009; Cadenas et al. 2010; Zellmer et al. 2010; Meyer et al. 2011), the establishment of pharmacokinetic and quantitative structure-activity models (Gundert-Remy et al. 2009; Bolt and Hengstler 2010; Hengstler et al. 2011; Mielke et al. 2011) or spatial-temporal models (Hoehme et al. 2007; 2010).

Even within the pages of our journal, the number of published papers on modelling has also increased in recent years (Lilienblum et al. 2008; Keller et al. 2009; Lehmann et al. 2010; Rupp et al. 2010; Golka et al. 2011). Therefore, experimentalists in the field of Toxicology can only gain if databases and bioinformatics are properly integrated into their experimental work. Unfortunately, this is currently not the case as many scientists may be discouraged by the complexity and missing user-friendliness of such databases. Therefore, it is highly appreciated that Karp and Caspy (2011; this issue) from the Bioinformatics Research Group in California accepted our invitation to contribute a review on metabolic databases. The review not only gives an overview of the numerous databases presently available, but also provides a user-friendly introduction for those not yet familiar with this type of software tools. Examples of 'quick search' queries which can be accomplished, even by beginners, within less than 5 min include as follows:

C. Cadenas $(\square) \cdot$ R. Marchan Leibniz Institut für Arbeitsforschung an der TU Dortmund, Leibniz Research Centre for Working Environment and Human Factors (IfADo), Ardeystrasse 67, 44139 Dortmund, Germany e-mail: cadenas@ifado.de
- Enter a metabolite of interest. The software will then show all known pathways on how this metabolite is further processed. For example, entering 'L-lysine' generates three pathways, two on the degradation of L-lysine and one tRNA charging pathway.

- Enter a gene or enzyme of interest. A 'regulation software' will then show all metabolites or protein factors that are involved in its regulation. For example, when the trpA gene is entered, tryptophan is highlighted because it also functions as a regulator at the transcriptional level. The software also returns the compound pyridoxal phosphate that activates the trpA, in addition to a small RNA molecule controlling translation of the trpA mRNA.

- Enter a pathway. The software will return all known enzymes involved. For example, upon entering 'glycolysis', the software shows 40 enzymes and their respective activities, which is certainly more than can be found in current textbooks or reviews.

Besides those easy to handle aspects, more complex functions can be processed, for example, the overlay of transcriptional datasets with metabolic activities. The review is a must-read for anyone interested in metabolic pathways and networks.

\section{References}

Bolt HM, Hengstler JG (2010) Testing of genetically modified novel proteins for allergenicity in food and feed: a toxicological and regulatory challenge. Arch Toxicol 84:907-908

Cadenas C, Franckenstein D, Schmidt M, Gehrmann M, Hermes M, Geppert B, Schormann W, Maccoux LJ, Schug M, Schumann A, Wilhelm C, Freis E, Ickstadt K, Rahnenführer J, Baumbach JI, Sickmann A, Hengstler JG (2010) Role of thioredoxin reductase 1 and thioredoxin interacting protein in prognosis of breast cancer. Breast Cancer Res 12:R44 
Glahn F, Schmidt-Heck W, Zellmer S, Guthke R, Wiese J, Golka K, Hergenröder R, Degen GH, Lehmann T, Hermes M, Schormann W, Brulport M, Bauer A, Bedawy E, Gebhardt R, Hengstler JG, Foth $\mathrm{H}$ (2008) Cadmium, cobalt and lead cause stress response, cell cycle deregulation and increased steroid as well as xenobiotic metabolism in primary normal human bronchial epithelial cells which is coordinated by at least nine transcription factors. Arch Toxicol 82:513-524

Godoy P, Hengstler JG, Ilkavets I, Meyer C, Bachmann A, Müller A, Tuschl G, Mueller SO, Dooley S (2009) Extracellular matrix modulates sensitivity of hepatocytes to fibroblastoid dedifferentiation and transforming growth factor beta-induced apoptosis. Hepatology 49:2031-2043

Golka K, Selinski S, Lehmann ML, Blaszkewicz M, Marchan R, Ickstadt K, Schwender H, Bolt HM, Hengstler JG (2011) Genetic variants in urinary bladder cancer: collective power of the "wimp SNPs". Arch Toxicol 85:539-554

Gundert-Remy U, Bernauer U, Madle S, Oberemm A, Schulte A, Richter-Reichhelm HB (2009) Letter to the editor: a regulatory view on the discussion on the role of alternative methods in the risk assessment of chemicals in the context of REACH. Arch Toxicol 83:9-10

Hengstler JG, Foth H, Gebel T, Kramer PJ, Lilienblum W, Schweinfurth H, Völkel W, Wollin KM, Gundert-Remy U (2011) Critical evaluation of key evidence on the human health hazards of exposure to bisphenol A. Crit Rev Toxicol 41:263-291

Hoehme S, Hengstler JG, Brulport M, Schäfer M, Bauer A, Gebhardt R, Drasdo D (2007) Mathematical modelling of liver regeneration after intoxication with $\mathrm{CCl}(4)$. Chem Biol Interact 168:74-93

Hoehme S, Brulport M, Bauer A, Bedawy E, Schormann W, Hermes M, Puppe V, Gebhardt R, Zellmer S, Schwarz M, Bockamp E, Timmel T, Hengstler JG, Drasdo D (2010) Prediction and validation of cell alignment along microvessels as order principle to restore tissue architecture in liver regeneration. Proc Natl Acad Sci USA 107:10371-10376

Karp PD, Caspy R (2011) A survey of metabolic databases emphasizing the MetaCyc family. Arch Toxicol. doi:10.1007/s00204-0110705-2 (this issue)
Keller D, Krauledat M, Scheel J (2009) Feasibility study to support a threshold of sensitization concern concept in risk assessment based on human data. Arch Toxicol 83:1049-1060

Lehmann ML, Selinski S, Blaszkewicz M, Orlich M, Ovsiannikov D, Moormann O, Guballa C, Kress A, Truss MC, Gerullis H, Otto T, Barski D, Niegisch G, Albers P, Frees S, Brenner W, Thüroff JW, Angeli-Greaves M, Seidel T, Roth G, Dietrich H, Ebbinghaus R, Prager HM, Bolt HM, Falkenstein M, Zimmermann A, Klein T, Reckwitz T, Roemer HC, Löhlein D, Weistenhöfer W, Schöps W, Beg AE, Aslam M, Bánfi G, Romics I, Ickstadt K, Schwender H, Winterpacht A, Hengstler JG, Golka K (2010) Rs710521[A] on chromosome 3 q28 close to TP63 is associated with increased urinary bladder cancer risk. Arch Toxicol 84(12):967-978

Lilienblum W, Dekant W, Foth H, Gebel T, Hengstler JG, Kahl R, Kramer PJ, Schweinfurth H, Wollin KM (2008) Alternative methods to safety studies in experimental animals: role in the risk assessment of chemicals under the new European Chemicals Legislation (REACH). Arch Toxicol 82:211-236

Meyer C, Godoy P, Bachmann A, Liu Y, Barzan D, Ilkavets I, Maier P, Herskind C, Hengstler JG, Dooley S (2011) Distinct role of endocytosis for Smad and non-Smad TGF- $\beta$ signaling regulation in hepatocytes. J Hepatol 55:369-378

Mielke H, Anger LT, Schug M, Hengstler JG, Stahlmann R, GundertRemy U (2011) A physiologically based toxicokinetic modelling approach to predict relevant concentrations for in vitro testing. Arch Toxicol 85:555-563

Rupp B, Appel KE, Gundert-Remy U (2010) Chronic oral LOAEL prediction by using a commercially available computational QSAR tool. Arch Toxicol 84:681-688

Zellmer S, Schmidt-Heck W, Godoy P, Weng H, Meyer C, Lehmann T, Sparna T, Schormann W, Hammad S, Kreutz C, Timmer J, von Weizsäcker F, Thürmann PA, Merfort I, Guthke R, Dooley S, Hengstler JG, Gebhardt R (2010) Transcription factors ETF, E2F, and SP-1 are involved in cytokine-independent proliferation of murine hepatocytes. Hepatology 52:2127-2136 